\title{
Using vegetation to characterize the avalanche of Canal del Roc Roig, Vall de Núria, eastern Pyrenees, Spain
}

\author{
Rigard MOLina, ${ }^{1}$ Elena MUNTÁn, ${ }^{2,3}$ Laia ANDreU, ${ }^{3}$ Glòria FURdAdA, ${ }^{4}$ Pere OLler, ${ }^{2}$ \\ Emilia GUTIÉRREZ, ${ }^{3}$ Pere MARTÍNEZ, ${ }^{2}$ Joan Manuel VILAPLANA ${ }^{4}$ \\ ${ }^{1}$ IGR EMAP S.L. Ignasi Grau Roca, Enginyeria, Medi Ambient, Paisatge, C/Carles Riba, 7-9, ES-18190 Sant Cugat del Vallès, Spain \\ ${ }^{2}$ Institut Cartogràfic de Catalunya, Generalitat de Catalunya, Parc de Montjuïc s/n, ES-08038 Barcelona, Spain \\ ${ }^{3}$ Departament Ecologia, Universitat de Barcelona, Av. Diagonal 645, ES-08028 Barcelona, Spain \\ ${ }^{4}$ RISKNAT Group, Departament Geodinàmica i Geofísica, Universitat de Barcelona, c/ Martíi Franquès s/n, ES-08028 Barcelona, Spain \\ E-mail: gloria.furdada@ub.edu
}

\begin{abstract}
Avalanche hazard maps of high accuracy are difficult to produce. For land-use planning and management purposes, a good knowledge of extreme run-out zones and frequencies of avalanches is required. In the present work, vegetation recognition (especially focused on Pinus uncinata trees) and dendrochronological techniques are used to characterize avalanches that have occurred in historical times, helping to determine both the extent of large or extreme avalanches and their occurrence in time. Vegetation was studied at the Canal del Roc Roig (eastern Pyrenees, Spain) avalanche path. The avalanches descending this path affect the railway that reaches the Vall de Núria resort and the run-up to the opposite slope. During winter 1996, two important avalanches affecting this path were well documented. These are compared with the results of the vegetation study, consisting of an inventory of flora, the recording of vegetation damages along eight transverse profiles at different altitudes on the path and a dendrochronological sampling campaign. The data obtained contributed to a characterization of the predominant snow accumulation in the starting zone, the 1996 avalanches and the range of frequencies of large avalanches. Also, traces of avalanches that increase the path mapped in the avalanche paths map published by the Institut Cartogràfic de Catalunya in 2000 were identified, improving the initial existing information.
\end{abstract}

\section{INTRODUGTION}

Avalanche hazard maps of high accuracy are difficult to produce. For land-use planning and management purposes, a good knowledge of extreme avalanches and their run-out zones and frequencies is required. In some cases, wellknown examples are provided by historical records (Buser and Fruttiger, 1980; Lied and Bakkehøi, 1980; McClung and others, 1989; Salm and others, 1990; Lied and others, 1995; Adjel, 1996; Furdada and others, 1998; Jóhannesson, 1998; Barbolini and others, 2000). In the Pyrenees, however, historical data are scarce, difficult to obtain or not very accurate, and sometimes they do not exist at all.

Vegetation and dendrochronological studies have intrinsic value as indicators of mountain ecological conditions. In the present work, vegetation (especially Pinus uncinata trees) is used as a tool that can provide data to characterize avalanches occurring in historical times. These data can help to determine both the extent of large or extreme avalanches and their occurrence in time. Previous works with the same aim are Potter (1969), Carrara (1979), Butler (1985), Butler and Malanson (1985), Bryant and others (1989) and Pelfini and others (2001).

Vegetation was studied at the Canal del Roc Roig avalanche path in Vall de Núria, eastern Pyrenees, Spain (coordinates in Universal Transverse Mercator (UTM) projection, spindle 31, Northern Hemisphere: 429500,4694500;
431000,4693500; see Muntán and others, 2004). It is an eastoriented catchment, drained by a torrent, with a maximum altitude of about $2400 \mathrm{~m}$ and an altitude at the bottom of the valley of about $1750 \mathrm{~m}$. The avalanches affect the railway (close to the bottom of the valley) to the Vall de Núria resort and the run-up to the opposite slope. The railway was built in 1929, so there are no historical avalanche data previous to that year. On the other hand, during winter 1996 two important avalanche events affected this path. Data on snow-cover conditions, avalanche characteristics and run-out distances are available for the two events. The avalanche cadastre compiled by the Institut Cartogràfic de Catalunya (ICC, 2002) includes the record of another avalanche that occurred in 1972. These data are compared with the results of the vegetation study in order to test the usefulness of the vegetation data as a guide to the characterization, extent and frequency of large avalanches.

\section{VEGETATION STUDY}

The vegetation study consisted of a detailed survey of the avalanche path and the selection of eight transverse profiles, covering a band $4 \mathrm{~m}$ wide, at different altitudes on the path (Fig. 1). Along these profiles, structural and quantitative parameters, some of them reflecting damages on trees, were classified, measured and recorded (i.e. dead or living trees, adult trees or young and stressed trees, visible wounds, trunk 


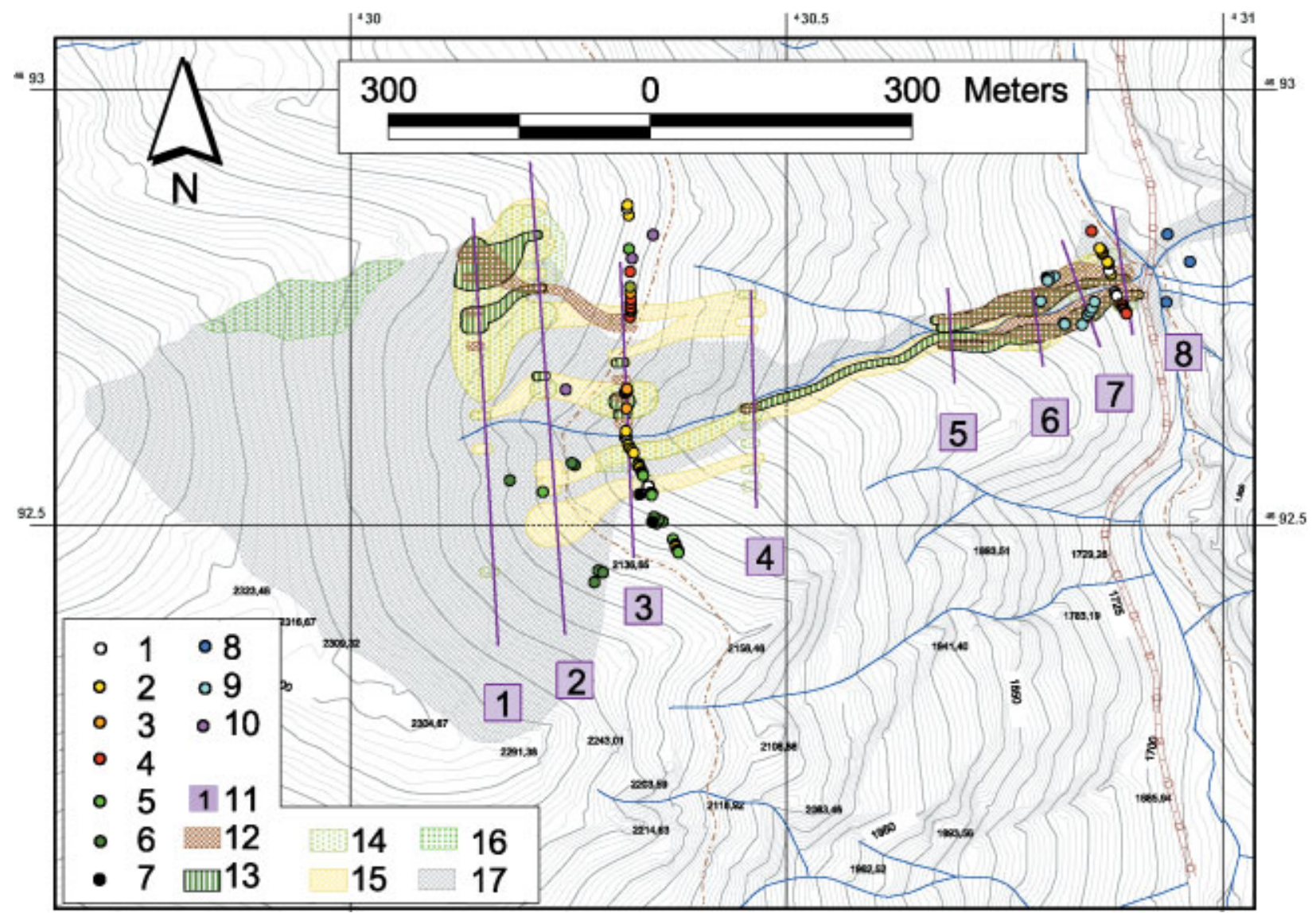

Fig. 1. Map of the vegetation data at Canal de Roc Roig. (1-7) Tree ages: (1) 0-20years; (2) 21-40 years; (3) 41-60 years; (4) 61-80 years; (5) 81-100 years; (6) 101-200 years; (7) 201-300 years. (8) Trees which show signs in the ring of the 1996 avalanches. (9, 10) Trees whose last growing season was: (9) 1995; (10) 1996. (11) Transverse-profiles location. (12) Dead and transported trees. (13) Dead, not transported trees, presenting wounds. (14) Adult, wounded trees. (15) Adult trees with tilted and curved trunks. (16) Community of Hieracio-Festucetum airoidis Br.-Bl.1948. (17) Canal del Roc Roig avalanche path mapped in the avalanche paths map (ICG, 2000).

form, distance to the central stream, diameter at breast height $1.30 \mathrm{~m}(\mathrm{DBH})$; Fig. 2). The types of differently damaged trees were also mapped in the field with the aid of aerial photos and orthophotos (Fig. 1). In addition, ten $10 \mathrm{~m} \times 10 \mathrm{~m}$ parcels, characterized by some floristic homogeneity and avoiding brusque changes related to the substratum and the topography, were selected and an inventory of flora was carried out.

A dendrochronological sampling campaign was also undertaken. Trees were sampled predominantly close to transverse profiles No. 3 in the track zone and No. 8 in the run-out zone, overlapping the limit of the avalanche path. Tree-ring cores and tree sections and wedges were obtained. The method used is presented in detail in Muntán and others (2004).

The data obtained from the vegetation and dendrochronological studies are synthesized in Figures 1 and 2.

\section{AVALANGHE DATA}

The study path is located in a region with major snowfalls coming from the east. North-to-northwestern winds are dominant, and often follow the eastern storms, redistributing the snow cover (Salvador, 1985; Mases and others, 1998).

In the case of the Roc Roig path, the prevailing winds are not seriously deflected by local topography, so the northernmost part of the catchment often experiences winter snowdrifts.

At this path, three large, naturally released avalanches were documented and compiled by the ICG (ICG, 2002; Table 1). The three avalanches reached at least as far as the railway (1745 $\mathrm{m}$ a.s.l.), and the two occurring during winter 1996 ran about 35-45 m up the opposite slope. The nivometeorological conditions during the two 1996 events are summarized in Table 2 and Figure 3. These two avalanches are mapped in Figure 4.

\section{RESULTS AND DISGUSSION}

The comparison of the avalanche and the vegetation and dendrochronological data allows us to outline some results.

In the northern part of transverse profile 1 (Figs 1 and 2), trees with diameters $<15 \mathrm{~cm}$ are dominant and reach the watershed. Some of these small trees present an apparently normal growth but are mixed with quite recently wounded trees, some with their main trunk broken, and some in situ dead trees and dead trees that underwent a short transport and indicate the direction of the valley (sometimes they are pulled up and the scar affecting the soil can be seen a few metres above). Figures 1 and 2 also show trees with inclined and curved trunks. All these damages can be interpreted as the result of an avalanche passage.

It is well known that the distribution pattern of several species (e.g. dwarf-shrub species) is strongly influenced by the distribution of the snow cover (Aulitzky, 1963; Grabherr and Mucina, 1993). A community of Hieracio-Festucetum airoidis 


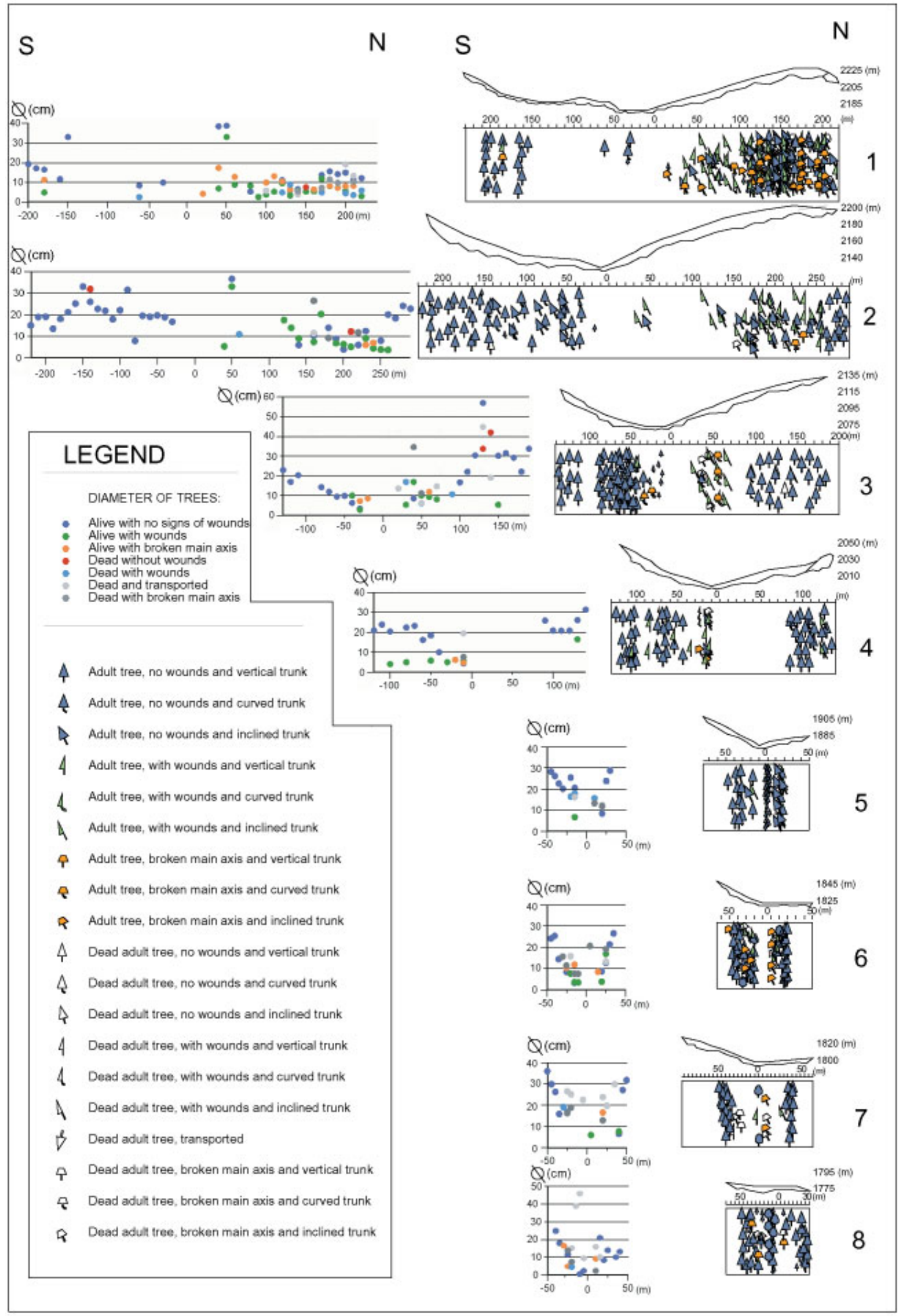

Fig. 2. Diagrams of the diameters of the recorded trees at $1.30 \mathrm{~m}$ DBH along the transverse profiles, and of the different types of wounds registered on the trees along the transverse profiles. The numbers at the right side of each transverse profile correspond to the numbers of the same profiles mapped in Figure 1. 
Table 1. Natural avalanches occurring at the Roc Roig path compiled in the ICC cadastre

\begin{tabular}{lcccc}
\hline Date & Type of avalanche & Starting altitude & Run-out & Width at railway \\
& & $\mathrm{m}$ & & $\mathrm{m}$ \\
\hline 18 January 1972 & ? & $?$ & Reached the railway (1745 m) & $?$ \\
Night 7-8 February 1996 & Mixed (dense + aerosol) & $?$ & Reached the railway; run-up till 1790 $\mathrm{m}$ & 70 \\
22 March 1996 & Wet (entrained soil + rocks) & 2175 & Reached the railway; run-up till 1780 $\mathrm{m}$ & 52 \\
\hline
\end{tabular}

Table 2. Snow and weather data recorded at Núria station (1970 m a.s.l.) related to the 1996 avalanches occurring at the Roc Roig path

\begin{tabular}{lccccccc}
\hline Avalanche date & Previous days & $\begin{array}{c}\text { New snow } \\
\mathrm{cm}\end{array}$ & $\begin{array}{c}\text { Total snow } \\
\mathrm{cm}\end{array}$ & $\begin{array}{c}T_{\max } \\
{ }^{\circ} \mathrm{C}\end{array}$ & $\begin{array}{c}T_{\min } \\
{ }^{\circ} \mathrm{C}\end{array}$ & $\begin{array}{c}\text { Wind speed } \\
\mathrm{ms}^{-1}\end{array}$ & $\begin{array}{c}\text { Wind direction } \\
\text { 7-8 February 1996 }\end{array}$ \\
& 5 February 1996 & 10 & 150 & -1 & -10 & 8 & west \\
& 6 February 1996 & 5 & 155 & -1 & -9 & 15 & northwest \\
22 March 1996 & 7 February 1996 & 15 & 150 & 0 & -9 & 1 & south \\
& 21 March 1996 & 0.1 & 126 & 7 & -2.5 & 2 & northwest \\
& 22 March 1996 & 0 & 122 & 9.5 & -1 & 1 & northwest \\
\hline
\end{tabular}

Br.-Bl.1948 was identified and mapped above this zone (Fig. 1). In the Pyrenees, this community appears at about 2300$2400 \mathrm{~m}$ a.s.l., as in the Roc Roig path, and reaches about 2800-2900 m a.s.l. It colonizes flat or slightly inclined zones and is usually covered by snow for approximately 7 months per year (Vigo, 1976; Folch, 1981; Bolós and others, 1993). In the area, altitude and aspect where this community is mapped, the long durability of the snow cover can only be explained by the existence of snowdrifts. The mapped community is located on a slightly inclined area (slope $10-20^{\circ}$ ),
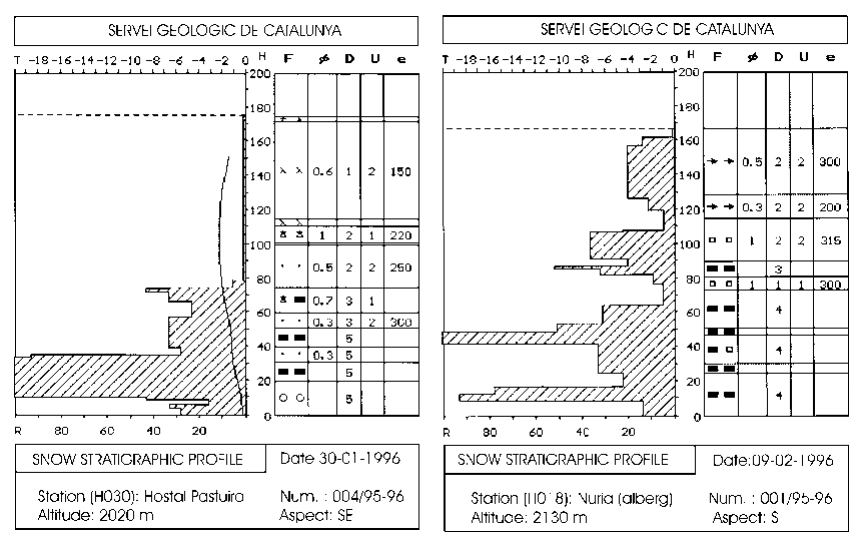

Fig. 3. Snow stratigraphic profiles; T: Temperature $\left({ }^{\circ} \mathrm{C}\right)$; $H$ : snow height; F: snow-grains form; $\phi$ : snow-grains diameter; $D$ : snow hardness (qualitative); $U$ : snow humidity (qualitative); e: snow density. Symbols correspond to the international classification for seasonal snow on the ground (Colbeck and others, 1990). (a) Snow profile corresponding to the second snowstorm period before the 7-8 February 1996 avalanche. It was recorded at Hostal Pastuira (2020 m a.s.l.), located about $10 \mathrm{~km}$ east of Vall de Núria but in the same climatic region. The new snow accumulated during this period was about $100 \mathrm{~cm}$ in this location. (b) Snow profile corresponding to the third snowstorm period before the 7-8 February 1996 avalanche. It was recorded at Vall de Núria (2130 m a.s.l.). The new snow accumulated during this period was about $60 \mathrm{~cm}$ in this location. leeward with respect to the watershed, taking into account the dominant winds, and therefore in a position that favours the formation of snowdrifts. At this altitude of the path, the trees present flag forms (with most branches growing southwards, offering minimum resistance to the wind), which also reflects the dominance of these northerly winds. The regular topography leads to the expectation of snowdrift formation all along the watershed, including the area of damaged vegetation described in the previous paragraph. All this is in accordance with what is known about this zone (see previous section).

Over-accumulation of snow can increase the inclination of the original slope and also favour the release of avalanches. The starting zone of the wet avalanche (22 March 1996) is well known and begins below this area. The mixed avalanche (78 February 1996) occurred after three snowstorm periods followed by strong northerly winds (Table 2; Fig. 3). The starting zone of this avalanche was approximated taking into account all these observations (Fig. 4).

At profile 3, all the northernmost trees show the effects of the avalanches of 1996 in the rings and also typical morphologies due to avalanche events. From these data, two hypotheses can be suggested: (1) that the wounds were caused by a small aerosol component related to the 7-8 February 1996 large, mixed avalanche event; (2) that the wounds were caused by small purges or slides produced in this area related to the high temperatures (Table 2) that triggered the 22 March 1996 avalanche. Until now, it has not been possible to test these hypotheses.

From the distribution of the damaged trees, their ages (Fig. 1) and their recorded diameters (Fig. 2), some morphologic-topographic control of the avalanches can be deduced. In transverse profiles 2-4, the mapped strips of damaged vegetation are separated by smooth topographic arêtes. Profile 3, with the exception of the northernmost trees (see previous paragraph), shows a progressive increase in tree ages from the torrent to the extremes, the youngest trees being located in the zone that tends to channelize the avalanches, closer to the axis of the torrent. This helps to identify the most frequent trajectories of the avalanches. At about 


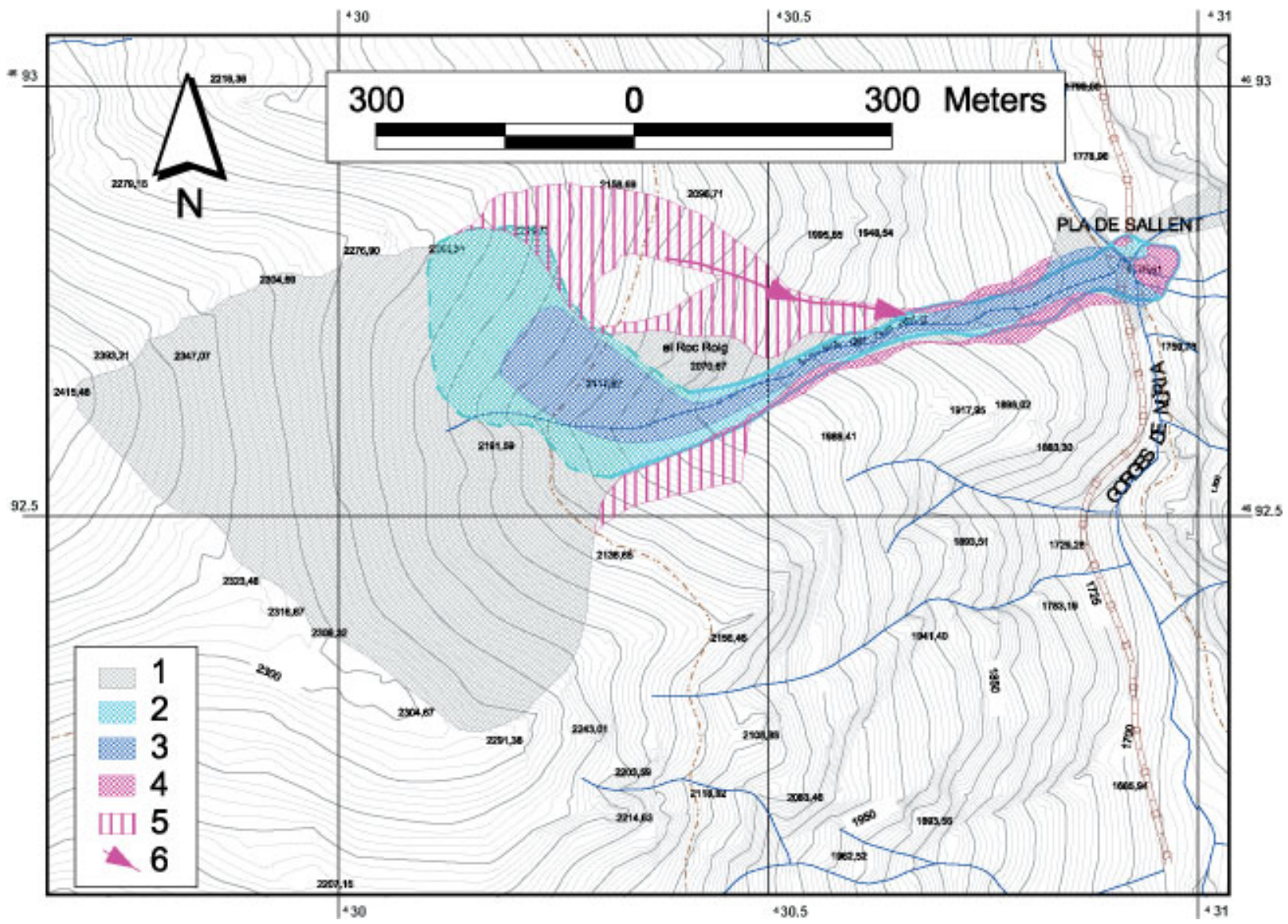

Fig. 4. Map of the avalanche path of Canal del Roc Roig: (1) Canal del Roc Roig avalanche path mapped in the avalanche paths map (ICC, 2000). (2) Avalanche of 7-8 February 1996 (starting-zone limits interpreted). (3) Avalanche of 22 March 1996. (4) Extent of the avalanche path of Canal del Roc Roig due to the vegetation and dendrochronological results. (5) Zone where avalanches of different sizes and direction can occur, from vegetation and dendrochronological results. (6) Zone where very confined avalanches occur, determined from vegetation and dendrochronological results and morphological indices.

$110 \mathrm{~m}$ (horizontal distance) north of the torrent, the regular forest begins. The difference in ages between the oldest and some intercalated younger trees is probably due to the internal forest dynamics (normal regeneration).

Along transverse profiles $1-4$, the coexistence of damaged and dead trees and trees with curved and inclined trunks can be observed, together with trees apparently not affected. The affected trees can only be detected by detailed fieldwork. Field observation from the opposite slope (which allows observation of the entire path) or the aerial photographs does not clearly indicate all the damages. Other reasons for damages and anomalous growth (e.g. rockfalls or soil creep) are not plausible here. Snow creep could be responsible for some curved trees, but not for all damages

Along the track zone, the dead and wounded trees and the trees with inclined and curved trunks (Fig. 1) indicate that the area affected by avalanches is wider than that mapped by the ICG (ICG, 2000) (Fig. 4). For the track and run-out zone ( $<2200 \mathrm{~m}$ a.s.l.), the avalanche path mapped by the ICG covers an area of 9.9 ha; the area mapped in the present work is 10.9 ha, which is $10.1 \%$ more than the initial area; when all the zone with avalanches of different sizes and difficult individualization is considered, the total path covers 15.4 ha, which is $55 \%$ more than the initial mapped area. This shows the importance of detailed studies of vegetation in selected paths. They provide much more valuable information than avalanche maps of scale 1:25000, made with budget and time limitations.
The records presented (including the two trees whose last growing season was 1996, close to the northern part of profile 3; see Fig. 1) seem to be consistent enough to increase to the north the limits of the avalanche path mapped in the avalanche paths map Núria-Freser (ICC, 2000; Fig. 4). At transverse profiles 5-7, in the lower part of the track and at the beginning of the run-out zones, the tree diameters seem to indicate the topographic control of the avalanches. Trees without apparent damages or anomalous growth can be identified at the edges of the channel; when they have diameters $>20 \mathrm{~cm}$ they do not coexist with damaged trees. Trees with these diameters grow at the topographic limits of the channel, behind arêtes or topographic inflexions, and are protected from the avalanches. These lateral limits approximately correspond to the limits of both the 1996 avalanches.

From the transverse profiles and the dead surveyed trees, the trajectory of the 7-8 February 1996 large avalanche can be deduced. It descended from the true left side of the torrent (which appears to be the most frequent), crossed it and then descended mostly along the right side (following a zigzag effect). The trajectory was not centred along the axis of the torrent. This trajectory is confirmed by the photographs taken after the event, which showed the main deposit of the avalanche at the right side of the channel.

Some of the dead trees transported to the run-out zone have diameters $>20 \mathrm{~cm}$ (including some $>40 \mathrm{~cm}$ ). This indicates that the 1996 avalanches affected zones of well-developed trees, not usually affected by these destructive events. 
Owing to differences in release position, flow direction and the behaviour of individual avalanches, there is an inherent variability in avalanche direction along the path (Keylock and others, 1999). Our data reflect the fact that not all the avalanches follow the same trajectory. Although there is an important topographic control in this path (strongly channelized along the track zone and with topographic constraints in the run-out zone), and although most of the avalanches that descend along this path are well-channelized, wet avalanches, and some of them run close to or reach the railway, small deviations along the trajectory occur when, as in this case, a mixed avalanche event occurs. In these cases, old trees can be affected and even broken and transported. Thus, inferences about the exceptionality of avalanches from the age of dead and transported trees should be made carefully. A few very old dead trees could imply just a deviation from the most frequent trajectory, and not always a really extreme avalanche (Muntán and others, 2004).

From the age of the trees close to transverse profile 8 (Fig. 1) the width of the 1972 avalanche at the railway was approximated to $55-60 \mathrm{~m}$. All the trees in the central part of this profile are younger than 40 years, so probably they began to grow after the 1972 avalanche. The trees at the edges of this profile are older than 40 years, so they mark the limit of the 1972 avalanche and they present wounded or tilted trunks. From the ICG cadastre data, it is known that mixed and wet avalanches occurred, but our data do not allow us to determine the type of avalanche. So what type of avalanche occurred in 1972 could not be deduced. This result is in accordance with the fact that avalanches with return periods of some tens of years reach at least as far as the railway (ICC, 2002).

In the run-up zone to the east of the railway, three trees (one Salix sp. and two Pinus uncinata; Fig. 1) show signs of a disturbance coming from the main, opposite slope in 1996: the one located at the southernmost position, the Salix sp., is tilted to the east, the central one shows signs affecting the tree rings, and the main trunk of the northernmost one was broken in 1996. These data correspond well with the observations of the 1996 avalanche deposits. This result shows the value of the dendrochronological studies.

\section{CONCLUSIONS}

We want to point out the usefulness of vegetation and dendrochronological studies. They help to characterize the most frequent distribution of the snow cover, and thus potential starting zones of avalanches; the vegetational communities reflect the durability of the snow cover and the snowdrifts that protect them. Adding this information to knowledge of the climatic characteristics of the region and observations of topography, roughness and inclination of the slopes, it should be possible to identify more accurately the potential starting zones of avalanches.

Also, these studies can be used to better understand the trajectories, run-out zones and frequencies of avalanches in a given path. With the scope of land-use planning, the vegetation and dendrochronological studies can help to identify the most frequent run-outs and to simulate avalanches more realistically when there is a lack of historical data to calibrate the dynamics models.

\section{ACKNOWLEDGEMENTS}

We are grateful for the collaboration of Vall de Núria mountain and ski resort, and the financial support of the following projects: RISKNAT (SGR2001 00081); MICYT: REN20000518; ALUDEX (MICYT-FEDER: REN2002-02768); and Programa Ramón y Cajal (Res. 20/12/2001).

\section{REFERENGES}

Adjel, G. 1996. Méthodes statistiques pour la détermination de la distance d'arrêt des avalanches. (Thèse de doctorat, Université Joseph Fourier Grenoble I.)

Aulitzky, H. 1963. Grundlagen und Anwendung des vorläufigen WindSchneeökgramms. Mitt. Forstl. Bundesversuchsanst. Wien 60, 765-834.

Barbolini, M., U. Gruber, C. J. Keylock, M. Naaim and F. Savi. 2000. Application of statistical and hydraulic-continuum dense-snow avalanche models to five real European sites. Cold Reg. Sci. Technol., 31 (2), 133-149.

Bolós, O., J. Vigo, R. Masalles and J. Ninot. 1993. Flora manual dels Paisos Catalans. Barcelona, Ed. Pòrtic.

Bryant, C. L., D. R. Butler and J. D. Vitek. 1989. A statistical analysis of treering dating in conjunction with snow avalanches: comparison of on-path versus off-path responses. Environ. Geol.Water Sci., 14(1), 133-171.

Buser, O. and H. Fruttiger. 1980. Observed maximum run-out distance of snow avalanches and the determination of the friction coefficients $\mu$ and $\xi$. F. Glaciol., 26(94), 121-130.

Butler, D. R. 1985. Vegetational and geomorphic change on snow avalanche paths, Glacier National Park, Montana, USA. Great Basin Naturalist, 45(2), 313-317.

Butler, D. R. and G. P. Malanson. 1985. A reconstruction of snow-avalanche characteristics in Montana, U.S.A., using vegetative indicators. F. Glaciol., 31 (108), 185-187.

Carrara, P. E. 1979. The determination of snow avalanche frequency through tree-ring analysis and historical records at Ophir, Colorado. Geol. Soc. Am. Bull., 90, 773-780.

Colbeck, S. C. and 7 others. 1990. The international classification for seasonal snow on the ground. Wallingford, Oxfordshire, International Association of Scientific Hydrology. International Commission on Snow and Ice.

Folch, R. 1981. La vegetació dels Països Catalans. Barcelona, Ed. Ketres.

Furdada, G., J. M. Vilaplana, E. Tomàs and D. Mas. 1998. The avalanche of la tartera de la Pica (Andorra). In Hestnes, E., ed. 25 Years of Snow Avalanche Research, Voss 12-16 May 1998. Proceedings. Oslo, Norwegian Geotechnical Institute, 104-107. (NGI Publication 203.)

Grabherr, G. and L. Mucina. 1993. Die Pflanzengesellschaften Österreichs.Vol. II. Jena, etc., Fischer.

Institut Cartogràfic de Catalunya (ICG). 2000. Núria-Freser. (Scale 1:25 000.) Barcelona, Servei Geològic de Catalunya. Institut Cartogràfic de Catalunya. (Mapa de zones d'allaus de Catalunya.)

Institut Cartogràfic de Catalunya (ICG). 2002. Conveni de seguiment geològic de la traça del Ferrocarril de Cremallera de Ribes-Núria. Informe sobre les allaus de neu. la fase. Barcelona, Servei Geològic de Catalunya. Institut Cartogràfic de Catalunya.

Jóhannesson, T. 1998. Icelandic avalanche runout models compared with topographic models used in other countries. In Hestnes, E., ed. 25 Years of Snow Avalanche Research, Voss 12-16 May 1998. Proceedings. Oslo, Norwegian Geotechnical Institute, 43-52. (NGI Publication 203.)

Keylock, C. J., D. M. McClung and M. M. Magnússon. 1999. Avalanche risk mapping by simulation. f. Glaciol., 45(150), 303-314.

Lied, K. and S. Bakkehøi. 1980. Empirical calculations of snow-avalanche run-out distance based on topographic parameters. f. Glaciol., 26(94), $165-177$.

Lied, K., C. Weiler, S. Bakkehøi and J. Hopf. 1995. Calculation method for avalanche run-out distance for the Austrian Alps. In Sivardière, F., ed. Les apports de la recherche scientifique à la sécurité neige, glace et avalanche. Actes de Colloque, Chamonix 30 mai-3 juin 1995. Grenoble, Association Nationale pour l'Étude de la Neige et des Avalanches (ANENA), 63-68.

Mases, M., D. Font and J. M. Vilaplana. 1998. Relationship between snowdrift development and drifted snow during a wind episode. Ann. Glaciol., 26, 144-148.

McClung, D. M., A. I. Mears and P. A. Schaerer. 1989. Extreme avalanche run-out: data from four mountain ranges. Ann. Glaciol., 13, 180-184.

Muntán, E., L. Andreu, P. Oller, E. Gutiérrez and P. Martínez. 2004. Dendrochronological study of the avalanche path Canal del Roc Roig: first results of the ALUDEX project in the Pyrenees. Ann. Glaciol., 38 (see paper in this volume).

Pelfini, M., M. Santilli, M. Caccianiga and F. Gironi. 2001. Un diverso approccio per lo studio delle valanghe. Dendrocronologia e fitosociologia. Neve e Valanghe 44, 10-16. 
Potter, N., Jr. 1969. Tree-ring dating of snow avalanche tracks and the geomorphic activity of avalanches, northern Absaroka Mountains, Wyoming. In Schumm, S. A. and W. C. Bradley, eds. United States contributions to Quaternary research: papers presented on the occasion of the VIII Congress of the International Association for Quaternary Research, Paris, France, 1969. Boulder, CO, Geological Society of America, 141-165. (Special Paper 123.)
Salm, B., A. Burkard and H. Gubler. 1990. Berechnung von Fliesslawinen: eine Anleitung für Praktiker mit Beispielen. Eidg. Inst. Schnee- und Lawinenforsch. Mitt. 47.

Salvador, F. 1985. Aportación al estudio nivoclimático del Pirineo Oriental. Notas de Geografía Física 13-14, 67-84.

Vigo, J. 1976. Lalta muntanya catalana, flora i vegetació. Barcelona XIX, Ed. Montblanc. 